\title{
Kemampuan Penyuluh Agama Islam Non PNS di Kabupaten Sumba Tengah dalam Menerapkan Teknik Komunikasi
}

\author{
Muhimatul Kibtiyah \\ Balai Diklat Keagamaan Denpasar
}

\begin{tabular}{|c|c|}
\hline & ABSTRACT \\
\hline $\begin{array}{l}\text { Keywords: } \\
\text { Communication; } \\
\text { Religious Counselor; } \\
\text { Informative; } \\
\text { Persuasive; } \\
\text { Koersive }\end{array}$ & $\begin{array}{l}\text { Abstract: This study aims to analyze the ability of non-civil servant religious } \\
\text { counselors in Central Sumba Regency in applying communication techniques. } \\
\text { This research uses a qualitative approach. The data source in this study is the } \\
\text { head of the KUA and Islamic religious counselors and fostered citizens. Data } \\
\text { collection techniques are done by observation, interview and document } \\
\text { analysis techniques. The results of the study stated that (1) the understanding } \\
\text { of religious instructors about good communication techniques was not yet } \\
\text { maximal (2) the ability of religious instructors to implement informative } \\
\text { communication techniques was already good (3) the ability of religious } \\
\text { instructors to implement persuasive communication techniques was quite } \\
\text { good (4) the ability of religious instructors in applying coercive } \\
\text { communication techniques is not optimal. }\end{array}$ \\
\hline $\begin{array}{l}\text { Kata kunci: } \\
\text { Komunikasi; } \\
\text { Penyuluh; } \\
\text { Informatif; } \\
\text { Persuasif; } \\
\text { Koersif }\end{array}$ & $\begin{array}{l}\text { Abstrak: Penelitian ini bertujuan menganalisis kemampuan penyuluh agama } \\
\text { non PNS di Kabupaten Sumba Tengah dalam menerapkan teknik komunikasi. } \\
\text { Penelitian ini menggunakan pendekatan kualitatif. Sumber data pada } \\
\text { penelitian ini adalah kepala KUA dan penyuluh agama Islam dan warga } \\
\text { binaan. Teknik pengumpulan data dilakukan dengan teknik observasi, } \\
\text { wawancara dan analisis dokumen. Hasil penelitian menyatakan bahwa (1) } \\
\text { Pemahaman penyuluh Agama tentang teknik komunikasi yang baik belum } \\
\text { maksimal ( } 2 \text { ) Kemampuan penyuluh Agama dalam menerapkan teknik } \\
\text { komunikasi informative sudah baik (3) Kemampuan penyuluh Agama dalam } \\
\text { menerapkan teknik komunikasi persuasive cukup baik (4) Kemampuan } \\
\text { penyuluh Agama dalam menerapkan teknik komunikasi koersif belum } \\
\text { maksimal. }\end{array}$ \\
\hline
\end{tabular}

Alamat Korespondensi:

E-mail: muhimatul.kibtiyah@gmail.com (Muhimatul Kibtiyah)

\section{Pendahuluan}

Penyuluh Agama Islam Non Pegawai Negeri Sipil merupakan mitra Direktorat Jenderal Bimbingan Masyarakat Islam Kementerian Agama yang melaksanakan tugas bimbingan dan penyuluhan untuk mewujudkan masyarakat Islam yang taat beragama dan sejahtera lahir batin. Dalam melakukan tugasnya, beberapa kemampuan dasar harus dimiliki oleh seorang Penyuluh, diantaranya adalah teknik melakukan komunikasi.

Keputusan Direktur Jenderal Bimbinagan Masyarakat Islam Nomor 298 Tahun 2017 tentang Pedoman Penyuluhan Agama Islam Non Pegawai Negeri Sipil menyebutkan bahwa Penyuluh Agama Islam Non PNS adalah seseorang yang diberi tugas, tanggungjawab, wewenang dan hak untuk melaksanakan kegiatan bimbingan dan penyuluhan di bidang keagamaan Islam dan pembangunan melalui bahasa agama.

Berdasarkan Keputusan Direktur Jendral Nomor 298 Tahun 2017, teknik komunikasi dalam menyampaikan informasi, telah diatur sedemikian rupa yaitu teknik komunikasi informative, 
persuasive dan koersif. Begitu pentingnya komunikasi dan pemahaman teknik komunikasi yang harus dikuasai oleh Penyuluh Agama, maka sangat penting Penyuluh memahami tekniknya karna keberhasilan pelaksanaan tugas penyuluh Agama Islam tidak terlepas dari kemampuan dalam berkomunikasi.

Penyuluh Agama Islam Kabupaten Sumba Tengah belum sepenuhnya memahami teknik Penyuluhan Agama dengan maksimal. Hal ini terlihat ketika Penyuluh melakukan praktik simulasi Penyuluhan Agama. Berdasarkan hal ini, penulis merasa perlu melakukan penelitian terkait pemahaman Penyuluh tentang Teknik Penyuluhan Agama.

Saat ini penyuluh Agama Islam non PNS di Kabupaten Sumba Tengah berjumlah 19 orang. Para penyuluh tersebut melaksanakan tugasnya sesuai dengan tugas pokok dan fungsinya, akan tetapi belum mendapatkan hasil yang optimal. Hal ini ditandai dengan kurangnya minat masyarakat untuk mengikuti dan merubah nilai-nilai negative yang selama ini sudah berlaku. Hal ini disebabkan kegigihan mereka dalam menerapkan kebiasaan lama yang telah diajarkan orangtua mereka secara turun temurun. Mereka menganggap bahwa hal tersebut sudah benar tanpa mengetahui sumber ilmunya.

Beberapa upaya telah dilakukan oleh Penyuluh Agama, diantaranya menyampaikan satu materi dengan cara berulang-ulang sampai mereka benar-benar memahami suatu masalah. Hal lain yang dilakukan adalah mengajak warga binaan untuk berdiskusi bersama meskipun sulit mengubah pandangan masyarakat yang sudah dipercaya secara turun temurun. Padahal selama ini, dalam melaksanakan tugasnya para penyuluh sudah mencaba melakukan beragam teknik komunikasi baik secara informative, persuasive, maupun koersif.

Penyuluh Agama Islam Non PNS berkoordinasi dengan Penyuluh Agama Islam Fungsional untuk melakukan penyuluhan agama Islam dalam bidang keislaman dan pembangunan sosial keagamaan, baik di lingkungan kementerian agama maupun lembaga mitra lintas sektoral. Adapun kompetensi yang diharapkan sesuai Peraturan Dirjen 298 Tahun 2018 adalah (1) Penyuluh Pemberantasan Buta Huruf al-Qur'an, yang bertugas untuk secara bertahap menjadikan kelompok binaan dapat membaca dan menulis huruf al-Qur'an; (2) Penyuluh Keluarga Sakinah, yang berperan untuk membentuk keluarga sakinah pada masyarakat; (3) Penyuluh Zakat, yang bertugas untuk meningkatkan pendayagunaan zakat dari dan untuk masyarakat; (4) Penyuluh Wakaf, yang bertugas untuk meningkatkan potensi dan pendayagunaan wakaf dari dan untuk masyarakat; (5) Penyuluh Produk Halal, yang bertugas menciptakan masyarakat muslim Indonesia yang sadar halal; (6) Penyuluh Kerukunan Umat Beragama, yang bertugas mendorong masyarakat untuk menciptakan kerukunan dalam kehidupan beragama; (7) Penyuluh Radikalisme dan Aliran Sempalan, yang bertugas untuk membantu instansi berwenang dalam pencegahan tumbuhnya perilaku radikal dan aliran sempalan di masyarakat dengan pendekatan agama; (8) Penyuluh Napza dan HIV/AIDS, yang bertugas untuk membantu instansi berwenang dalam proses rehabilitasi pengguna Napza dan ODHA dengan pendekatan spiritual

Komunikasi berasal dari bahasa Inggris communication berasal dari kata latin communicatio dan bersumber dari kata communi yang berarti sama. Sama di sini adalah sama makna, menurut Effendi (2005). Istilah teknik berasal dari bahasa Yunani yaitu dari kata technikos yang berarti keterampilan atau kecakapan. Berdasarkan keterampilan berkomunikasi yang dilakukan komunikator, teknik komunikasi diklasifikasikan menjadi tujuh menurut Effendi (2005), yaitu: (1) Komunikasi informatif (informative communication); Adalah pesan yang disampaikan dari kepada penerima pesan sehingga dengan tujuan mereka dapat mengetahuinya. (2) Komunikasi persuasif (persuasive communication); Adalah pesan yang disampaikan kepada komunikan dengan tujuan dapat mengubah sikap, pendapat dan perilakunya. (3) Komunikasi pervasif (pervasive communication); Adalah pesan yang disampaikan sehingga komunikan dapat meresapi isi dari komunikasi tersebut. (4) Komunikasi koersif (coersive communication); Adalah pesan yang disampaikan dengan adanya paksaan. (5) Komunikasi instruktif (instructive communication); Komunikasi instruktif disebut juga sebagai komunikasi koersif karna sama-sama mengandung perintah, ancaman, sanksi yang bersifat memaksa. (6) Hubungan manusiawi (human relations); Merupakan komunikasi yang dilakukan dengan mempertimbangkan nilai-nilai kemanusiaan. 
Adapun teknik komunikasi oleh Penyuluh Agama diatur sedemikian rupa sesuai Peraturan Direktorat Jenderal Nomor 298 Tahun 2017 adalah (1) Komunikasi informatif, teknik ini dilakukan dengan cara menyampaikan pesan yang sifatnya "memberi tahu" atau memberikan penjelasan kepada orang lain. Komunikasi ini dapat dilakukan secara lisan maupun tertulis, yang sifatnya informatif dansatu arah(one way communication). Penggunaan teknik ini bertujuan untuk menyampaikan sesuatu yang dianggap penting oleh kelompok binaan; (2) Komunikasi persuasif, yaitu Komunikasi ini digunakan dengan cara membujuk, mengajak dan meyakinkan masyarakat untuk mempengaruhi pemikiran serta mengubah sikap dan perilakunya ke arah yang diinginkan penyuluh. Teknik komunikasi persuasif dilakukan melalui tatap muka,karena penyuluh mengharapkan tanggapan/respon khusus dari warga binaan; (3) Komunikasi koersif, yaitu komunikasi ini adalah proses penyampaian pesan dari penyuluh agama Islam kepada masyarakat dengan cara yang mengandung paksaan agar melakukan suatu tindakan atau kegiatan tertentu. Teknik ini mengandung sanksi yang apabila tidak dilaksanakan oleh si penerima pesan, maka ia akan menanggung akibatnya. Komunikasi ini dapat dilakukan dalam bentuk putusan-putusan, instruksi dan lain-lain yang sifatnya imperatif, yang mengandung keharusan dan kewajiban untuk ditaati dan dilaksanakan.

Rumusan masalah dalam penelitian ini, disusun dalam bentuk pertanyaan penelitian berikut (1) Apakah Penyuluh Agama Islam non PNS di Kabupaten Sumba Tengah memahami teknik penyuluhan agama dengan baik? (2) Bagaimanakah kemampuan Penyuluh Agama Islam non PNS di Kabupaten Sumba Tengah dalam menerapkan teknik komunikasi informatif? (3) Bagaimanakah kemampuan Penyuluh Agama Islam non PNS di Kabupaten Sumba Tengah dalam menerapkan teknik komunikasi persuasif? (4) Bagaimanakah kemampuan Penyuluh Agama Islam non PNS di Kabupaten Sumba Tengah dalam menerapkan teknik komunikasi koersif

Sesuai dengan rumusan masalah yang telah disebutkan, tujuan Penelitian ini adalah untuk (1) Mengetahui pemahaman Penyuluh Agama tentang teknik penyuluhan agama, (2) Mengetahui kemampuan Penyuluh Agama Islam non PNS di Kabupaten Sumba Tengah dalam menerapkan teknik komunikasi informatif (3) Mengetahui kemampuan Penyuluh Agama Islam non PNS di Kabupaten Sumba Tengah dalam menerapkan teknik komunikasi persuasif (4) Mengetahui kemampuan Penyuluh Agama Islam non PNS di Kabupaten Sumba Tengah dalam menerapkan teknik komunikasi koersif

Penelitian ini diharapkan bermanfaat bagi (1) Kantor Urusan Agama Kabupaten Sumba Tengah. Dengan mengetahui kemampuan penyuluhnya, Kepala KUA akan dapat mengambil tindakan sesuai dengan kemampuan penyuluhnya. (2) adapun bagi Penyuluh Agama, setelah mengetahu hasil penelitian ini, diharapkan Penyuluh Agama Non PNS Kabupaten Sumba Tengah dapat menerapkan teknik kemunikasi yang sesuai dengan keadaan kelompok binaannya (3) Masyarakat diharapkan akan lebih optimal berkomunikasi dengan penyuluh Agama.

Penelitian terkait dengan penelitian ini telah dilakukan sebelumnya oleh Zaenuri (2017) menyatakan bahwa, penggunaan komunikasi persuasif dalam dunia pendidikan dapat mendukung keberhasilan proses belajar mengajar. Proses komunikasi dan interaksi antara guru dan siswa yang dibangun dengan komunikasi persuasif akan memunculkan sifat kesadaran ang dimilki oleh murid, selain dari itu murid akan senantiasa meniru prilaku dan atau ucapan pendidik, karena pendidik merupakan komunikan utama dalam proses belajar mengajar.

Penelitian lain yang berjudul Teknik Komunikasi Informatif dalam Kegiatan Orientasi Penyuluh Agama Terhadap Calon Pengantin Oleh Badan DKP3A di Samarinda oleh Putra (2018) menunjukan hasil bahwa teknik komunikasi informatif oleh Badan DKP3A Prov. Kaltim terkait pelaksanaan kegiatan orientasi terhadap tenaga penyuluh agama di Samarinda sudah baik, dilihat dari berdasarkan fakta, pesan ditujukan untuk perluasan wawasan, dan pesan bertujuan untuk memberikan informasi serta motivasi. Akan tetapi, teknik komunikasi terkait informasi tentang kejelasan pesan masih terdapat informasi yang belum jelas dan pesan ditujukan untuk perluasan wawasan masih minim dikarenakan kegiatan yang sehubungan dengan hal tersebut masih jarang dilaksanakan. 
Adapun penelitian lain yang dilakukan oleh Pertiwi (2019) menunjukkan hasil berbeda. Hasil penelitian ini menunjukan bahwa PT. BNI (Persero) Tbk Kantor Cabang Padang menggunakan tiga strategi komunikasi persuasif untuk meningkat jumlah debitur, yang pertama yaitu menggunakan strategi melalui pendekatan emosional (strategi psikodinamika) dengan cara menarik perhatian, membangun unsur kepercayaan dan memanfaatkan situasi, yang kedua menggunkan strategi melalui pendekatan sosial (strategi sosiokultural) melalui lingkungan keluarga dan lingkungan teman, yang ketiga menggunakan strategi dengan cara memberikan pengetahuan tentang perusahaan (the meaning contruction) dengan cara personal selling dan melalui media. Kemudian dalam meningkatkan jumlah debitur PT. BNI (Persero) Tbk Kantor Cabang Padang menggunkan teknik the yes-respons technique dengan cara memberikan pertanyaan atau pernyataan kemudian menggunkan teknik don't ask if ask which dengan cara menawarkan pilihan.

Penelitian yang dilakukan Zaenuri (2017) dan Pertiwi (2019) lebih khusus pada penelitian komunikasi dengan teknik persuasif. Adapun penelitian yang dilakukan oleh Putra (2018) adalah khusus membahas tentang penelitian komunikasi dengan teknik informatif. Penelitian ini mencoba melakukan penelitian secara menyeluruh tiga teknik, yaitu teknik informatif, persuasif dan koersif yang didasarkan Peraturan Dirjen Nomor 298 Tahun 2017.

Selanjutnya, peneliti mencoba menganalisis beberapa hal yang menyebabkan kurang maksimalnya penerapan teknik komunikasi tersebut._Berdasarkan latar belakang inilah, penulis tertarik untuk mengumpulkan data untuk mengetahui kemampuan penyuluh Agama dalam melakukan komunikasi dengan masyarakat ketika melaksanakan kegiatan penyuluhan agama di Kabupaten Sumba Tengah. Selanjutnya hasil penelitian ini, penulis susun dalam sebuah laporan penelitian dengan judul "Kemampuan Penyuluh Agama Non PNS di Kabupaten Sumba Tengah dalam Menerapkan Teknik Komunikasi Informatif, Persuasif dan Koersif."

\section{Metode}

Penelitian ini menggunakan pendekatan kualitatif, yaitu prosedur penelitian yang menghasilkan data deskriptif berupa kata-kata tertulis atau lisan dari orang-orang atau perilaku yang dapat diamati Moleong (2005). Penelitian ini dilakukan di Kabupaten Sumba Tengah. Penelitian dilakukan pada bulan Februari 2020. Alasan pemilihan lokus ini adalah karena Penyuluh di Sumba Tengah belum mendapatkan materi Diklat Penyuluh. Diklat Penyuluh Non PNS merupakan Diklat yang dilakukan untuk meningkatkan kompetensi Penyuluh Agama.

Sumber data utama dalam penelitian ini adalah kepala KUA dan penyuluh agama Islam Kabubaten Sumba Tengah dan warga binaan Penyuluh Agama Islam Kabupaten Sumba Tengah. Penyuluh agama terdiri dari penyuluh agama Islam, Kristen dan Katolik. Adapun sumber data sekunder adalah kelompok pengajian, perkumpulan agama di Kabupaten Sumba Tengah.

Pengumpulan data dalam penelitian ini dilakukan dengan teknik (1) Observasi, yaitu teknik pengumpulan data dengan cara mengamati gerak gerik, kemampuan komunikasi penyuluh non PNS dalam melakukan kegiatan penyuluhan. Instrumen yang digunakan adalah daftar observasi, (2) Wawancara, yaitu Penulis melakukan wawancara dengan mengajukan pertanyaan kepada sumber data utama dan pertanyaan kepada sumber data skunder. Instrumen yang digunakan daftar wawancara dalam bentuk geogle form, (3) Analisis Dokumen, yaitu teknik pengumpulan data untuk memperoleh data dan informasi melalui cara menelaah dokumen seperti program kerja, laporan bulanan penyuluh Agama non PNS Kabupaten Sumba Tengah.

Data yang diperoleh dalam penelitian ini akan dianalisa dengan menggunakan teknik analisis tematik. Peneliti menentukan tema dan memilah data berdasarkan tema. Selanjutnya peneliti melakukan reduksi data, mengorganisasikan dan melakukan verifiikasi data dalam tiap tema. Setelah data-data yang kredibel terkumpul, penulis melakukan penafsiran dan analisis secara deskriptif. Pada akhir kegiatan penelitian, penulis menyusun laporan dalam format laporan hasil penelitian kualitatif. Laporan hasil penelitian kualitatif ini diuraikan dengan menggunakan kalimat yang logis yang dibahas 
dengan teori yang mendukung untuk mendapatkan sebuah konklusi.Berisi bagaimana data dikumpulkan, sumber data dan cara analisis data.

\section{Hasil dan Pembahasan}

\section{Pemahaman Teknik Komunikasi}

Penyuluh Agama Islam Non PNS di Kabupaten Sumba Tengah belum maksimal dalam memahami Teknik Komunikasi. Hal ini terlihat pada saat wawancara. Rata-rata Penyuluh belum memahami adanya teknik komunikasi Koersif. Selama melakukan penyuluhan, teknik komunikasi yang terbiasa diterapkan adalah teknik komunikasi informatif dan persuasif. Adapun pemahaman terhadap istilah teknik komunikasi informatif, persuasif dan koersif, sebagian besar Penyuluh baru mengetahui dari keikutsertaan Diklat ini. Dapat disadari minimnya pemahaman Penyuluh pada istilah tersebut, karena Penyuluh Agama Islam Non PNS di Kabupaten Sumba Tengah relatif baru diangkat dan semua Penyuluh Agama tidak berlatar belakang ilmu komunikasi.

\section{Penerapan Teknik Komunikasi Informatif}

Hasil penelitian tentang kemampuan penyuluh agama di Kabupaten Sumba Tengah dalam menerapkan teknik komunikasi informatif, persuasif dan koersif dapat diuraikan sebagai berikut:

1) Pemahaman Penyuluh Agama Islam non PNS di Kabupaten Sumba Tengah tentang teknik penyuluhan agama belum maksimal. Hal ini terlihat dari kepiawaian menggunakan teknik komunikasi. Tiga teknik komunikasi dapat digunakan sesuai tingkat kepentingan komunikasi yang perlu disampaikan.

2) Kemampuan Penyuluh Agama Islam non PNS di Kabupaten Sumba Tengah dalam menerapkan teknik komunikasi informatif sudah baik. Berdasarkan kemampuan latar belakang pendidikan Penyuluh Agama dan pemahaman terhadap isi materi yang disampaikan, Penyuluh menyampaikan komunikasi dengan teknik informatif dengan cara yang baik. Meskipun beberapa diantara Penyuluh Agama belum menyelesaikan Pendidikan Strata satu, tetapi Penyuluh mempunyai latar belakang ilmu agama dari pendidikan di pesantren. Kelompok binaan terutama yang tinggal di pedalaman, ketika mendengar informasi agama dari seseorang yang mempunyai latar belakang pesantren, akan lebih cepat menerima informasi tersebut.

\section{Penerapan Teknik Komunikasi Persuasif}

Kemampuan Penyuluh Agama Islam non PNS di Kabupaten Sumba Tengah dalam menerapkan teknik komunikasi persuasive cukup baik. Berdasarkan pengalaman menjadi seorang Penyuluh, beberapa Penyuluh mempunyai pengalaman yang baru dalam bidang penyuluhan. Beberapa Penyuluh masih mengalami masalah dengan pandangan masyarakat yang menganggap bahwa seseorang yang menyampaikan agama adalah orang yang lebih tua. Berdasarkan hasil wawancara dengan Penyuluh, Penyuluh akan menerapkan metode pembelajaran orang dewasa setelah mendapatkan pengalaman belajar dari pelaksanaan kegiatan Diklat. Selama ini, penyuluhan hanya dilakukan dengan berdakwah dengan metode ceramah. Setelah mengikuti kegiatan Diklat, Penyuluh akan mengkolaborasikan dengan melibatkan kelompok binaan secara aktif.

Adapun penerapan metode penyampaian materi bagi Penyuluh spesialisasi pemberantasan buta aksara alQur'an akan menyampaikan materi dengan cara yang lebih menarik lagi. Beberapa cara adalah dengan mengemas penyampaian pembelajaran ilmu tajwid dengan lebih menarik. Berdasarkan pengalaman dari pelaksanaan Diklat, mereka akan menerapkan metode permainan domino dipadu dengan ilmu tajwid. Teknik berbeda yang diterapkan pada kelompok binaan diharapkan mampu membuat kelompok binaan lebih tertarik pada informasi yang disampaikan oleh Penyuluh. Selanjutnya, setelah kelompok binaan tertarik dengan informasi yang disampaikan penyuluh, harapan selanjutnya adalah tujuan komunikasi tersampaikan. 


\section{Penerapan Teknik Koersif}

Kemampuan Penyuluh Agama Islam non PNS di Kabupaten Sumba Tengah dalam menerapkan teknik komunikasi koersif kurang maksimal. Pada dasarnya penyampaian komunikasi dengan teknik koersif ini memerlukan pengalaman khusus, penguasaan terhadap regulasi suatu masalah yang ingin disampaikan. Karena apabila tidak memahami regulasi dan penguasaan masalah secara baik, warga binaan akan meragukan kemampuan Penyuluh.

Berdasarkan hasil observasi di lapangan bahwa teknik komunikasi yang terjadi antara penyuluh agama dan warga binaan, umumnya menggunakan tiga teknik yaitu teknik informatif, teknik persuasif dan teknik koersif sesuai PMA 298 Tahun 2017. Teknik penyuluhan dengan teknik komunikatif ini sesuai dengan hasil wawancara dengan informan penyuluh agama Islam di Sumba Tengah dengan logat Sumba bercampur logat Bima. "pengetahuan agama masyarakat masih minim, jadi tata cara ibadah mereka masih ikut orang tua atau nenek moyang mereka. Macam begini ibuk, pada pergerakan sholat, waktu tasyahud itu kaki yang seharusnya begini (condong kanan) tapi dilipat begini (condong ke kiri). Hal seperti ini kita kasi tahu juga."

Teknik persuasif dilakukan pada beberapa keadaan oleh beberapa penyuluh agama, diantaranya terekam pada pembicaraan sebagai berikut: "yang terlebih ini, pemahaman mereka apabila tidak sholat subuh, mereka tidak sholat dhuhur. Ketika saya tanya "kenapa begitu?", katanya dulu mereka diajarkan orang tua sholat pembuka adalah sholat subuh. Makanya ketika sholat subuh tidak dikerjakan, maka sholat selanjutnya tidak dikerjakan, mereka tidak sholat selama satu hari. Mereka menganggap bahwa terbitnya fajar sampai nanti mau terbitnya matahari. Nah di situlah kami masuk dan menerangkan pada mereka kemudian mengajak mereka untuk sholat." Selanjutnya, informan agama lain menyampaikan:"apabila tata cara sholat itu sudah berulang kali tidak dilakukan, akhirnya kami paksa mereka untuk melakukan sesuai dengan kaidah ilmu fiqih, Ibu. Kami sampaikan bahwa apa yang mereka praktikkan dari nenek moyang mereka itu tidak sesuai dengan syariat Islam."

Berdasarkan pembahasan yang telah disampaikan, bahwa pemahaman Penyuluh Agama non PNS kabupaten Sumba tentang teknik komunikasi yang baik belum maksimal. Kemampuan penyuluh Agama non PNS kabupaten Sumba dalam menerapkan teknik komunikasi informative sudah baik. Kemampuan penyuluh Agama non PNS kabupaten Sumba dalam menerapkan teknik komunikasi persuasive cukup baik. Kemampuan penyuluh Agama non PNS kabupaten Sumba dalam menerapkan teknik komunikasi koersif belum maksimal.

\section{Simpulan}

Simpulan dari hasil penelitian ini adalah (1) Pemahaman penyuluh Agama non PNS kabupaten Sumba tentang teknik komunikasi yang baik belum maksimal sehingga belum semua teknik dapat digunakan untuk tercapainya tujuan komunikasi (2) Kemampuan penyuluh Agama non PNS kabupaten Sumba dalam menerapkan teknik komunikasi informatif sudah baik (3) Kemampuan penyuluh Agama non PNS kabupaten Sumba dalam menerapkan teknik komunikasi persuasif cukup baik (4) Kemampuan penyuluh Agama non PNS kabupaten Sumba dalam menerapkan teknik komunikasi koersif belum maksimal.

\section{Ucapan terimakasih}

Rasa terimakasih disampaikan kepada Balai Diklat Keagamaan Denpasar yang telah menugaskan penulis di Kabuaten Sumba Tengah sehingga dapat menulis pengalaman kegiatan Diklat di Kabupaten tersebut. Terimakasih juga penulis ucapkan kepada Kepala Kantor Kementerian Agama beserta jajaran atas semua bantuan fasilitas dan lainnya sehingga kegiatan Diklat dapat terlaksana dengan lancer. Bagi Penyuluh Agama, diucapkan terimakasih karna telah bersedia membagi pengalaman untuk dapat ditulis. 


\section{Daftar Pustaka}

Keputusan Direktur Jenderal Bimbingan Masyarakat Islam Nomor 298 Tahun 2017 Tentang Pedoman Penyuluh Agama Islam Non Pegawai Negeri Sipil

KMA, Nomor 164 Tahun 1996 tanggal 26 April 1996 tentang Honorarium Penyuluh Agama

Moleong, L. J. 2006. Metodologi Penelitian Kualitatif. Bandung: PT Remaja Rosdakarya.

Effendi, O.C. 2005. Ilmu Komunikasi: Teori Dan Praktek. Bandung: PT. Remaja Rosdakarya.

Pertiwi, D. dan Nurjanah. 2019. Strategi Komunikasi Persuasif dalam Meningkatkan Jumlah Debitur di PT BNI (Persero) TBK Kantor Cabang Padang. JOM Fisip. Vol. 6. Edisi 1. Hal 1-14

Putra, R.K. dkk. 2018. Teknik Komunikasi Informatif dalam Kegiatan Orientasi Penyuluh Agama Terhadap Calon Pengantin Oleh Badan DKP3A di Samarinda. E-Journal Ilmu Komunikasi. Vol. 6 No. 3. Hal. 438-451

Zaenuri, A. 2017. Teknik Komunikasi Persuasif dalam Pengajaran. Journal of Applied Linguistics and Islamic Education. Volume 01. Nomor 01. H. 41-67 